\title{
Anticancer activity of isolated compounds from twigs of Koelreuteria elegans cultivated in Egypt
}

\author{
Fatma Abo-EIghiet ${ }^{1, *}$, Magda T. Ibrahim ${ }^{1}$ and Amany A. Sleem ${ }^{2}$ \\ ${ }^{1}$ Department of Pharmacognosy, Faculty of Pharmacy (Girls), Al-Azhar University, Cairo, Egypt. \\ ${ }^{2}$ Department of Pharmacology, National Research Centre, Giza, Egypt. \\ * Correspondence e mail, fatmaaboelghiet731.el@azhar.edu.eg
}

Article history: Received 2020-12-16 Revised 2021-02-15 Accepted 2021-04-02

\begin{abstract}
Phytochemical constituents have been participated with essential role in the discovery of several clinically effective anticancer agents. The goal of this study was to isolate phytoconstituents from Koelreuteria elegans twigs (Sapindacea family) and evaluate their anticancer activities against human lung, colon and breast cancer cell lines. The aqueous methanol extract of plant's twigs was fractionated with different solvents and the preliminary cytotoxicity of fractions was determined using brine shrimp lethality assay. Nine compounds from $K$. elegans twigs butanol fraction were isolated for the first time; gallic acid (1), methyl gallate (2), 6- $O$ - [Galloyl 4- methyl ether]-( $\alpha / \beta)$-D-glucopyranose (3), 3, 5-di- $O$-galloylquinic acid butyl ester (4), 3,4,5-tri- $O$ galloylquinic acid butyl ester (5), 1,3,4,5-tetra- $O$-galloylquinic acid butyl ester (6), two isomers of 3-O-galloyl quinic acid butyl ester and 4-O-galloyl quinic acid butyl ester (7), austrobailignan 1 (8) and $\beta$-sitosterol (9). The structures of compounds were elucidated using different spectroscopic techniques. Anticancer activities of butanol fraction, methyl gallate and austrobailignan 1 were estimated in-vitro by cell viability assay. The results showed significant anticancer activity of both methyl gallate and austrobailignan 1 against breast cancer cell lines and less cytotoxicity against colon cell lines while almost no activity against lung cell lines.
\end{abstract}

Keywords: Koelreuteria elegans; Gallic Acid; Methyl Gallate; Austrobailignan 1; Anticancer; Brine Shrimp; Cell Lines.

\section{INTRODUCTION}

Cancer is a broad term used to indicate a number of chronic diseases. It is characterized by uncontrolled cell division that leads to abnormal tissue growth. There are many types of cancer, as any type of cells can be affected, these affected abnormal cells can spread to other body parts causing new tumor which is known as metastasis ${ }^{1}$. According to WHO data in 2018, lung, breast and colorectal cancer are the most prevalent types of cancer. While lung cancer and colorectal cancer are always the most common causes of death. Some of the most common cancer types, such as breast, cervical, oral and colorectal cancers are extensively curable if they are discovered early and treated suitably ${ }^{2}$. Cancer deaths are projected to rise continuously to be 11.5 million deaths in 2030 and 17.5 million deaths in 2050. Surgery, radiation therapy and chemotherapy are the most common cancer treatments. Despite that, natural sources, especially plants, are exemplary sources for discovery of new anticancer agents to overcome the side effects of chemotherapy and radiotherapy ${ }^{3}$. Investigation of plant extracts and their bioactive components for numerous pharmacological activities, such as anticancer activity, is one of the most significant areas of research since the last few decades $^{4}$

Koelreuteria, a genus in Sapindacea family, includes four famous ornamental tree species which sometimes used for their timber ${ }^{5}$. These species are characterized by bacteriostatic ${ }^{6}$, antifungal ${ }^{7}$, insecticidal $^{8}$, anti-inflammatory (mainly in gout), antitumor and anti-oxidation activities ${ }^{10,11}$. The two species, Koelreuteria elegans A. C. Sm. and Koelreuteria henryi Dümmer, are considered as two subspecies due to great similarity between them. In Taiwan folk medicine, $K$. henryi has been used for the treatment of hepatitis, enteritis, hypertension, pharyngitis, cough, allergy, hyperlipidemia, and cancer, while $K$. elegans leaves are used as a black hair dye $\mathrm{e}^{10,12,13}$. Although various classes of compounds have been reported to be isolated from different species of the genus Koelreuteria including flavonoids, cyclolignans, organic acids, sterols, cyanolipids, triterpenoid glycosides as well as gallate derivatives $^{10,14,15}$, a little work has been reported concerning $K$. elegans. At the same time, its twigs aqueous methanol extract exhibited crowded phenolic 2D-PC chromatogram. Therefore, the investigation of the phytochemical and anticancer activity of $K$. elegans twigs was the goal of this study. Fractionation of $K$. elegans aqueous methanol extract by different solvent systems was done. Then the use of Brine

Cite this article: Abo-Elghiet, F., Ibrahim, M., Sleem, A. Anticancer activity of isolated compounds from twigs of 
Shrimp Lethality Assay (BSLA) as a preliminary guide to estimate the cytotoxicity of fractions. The cytotoxic active fraction undergoes quantitative detection of its phenolic content then isolation and structure elucidation of its main components using different spectroscopic techniques. Finally, the evaluation of the antineoplastic activities of this fraction and its major pure phytoconstituents was done in-vitro against lung, breast and colon human cancer cell lines. As these three cell lines are the most common cancer types and for the previous reported data of anticancer activity of the isolated cyclolignans from the leaves of the closely related species $K$. henryi against these cell lines.

\section{METHODS}

\subsection{General equipment and chemicals}

NMR analysis was carried out using Bruker spectrometer (Boston, USA) operating at (500 $\mathrm{MHz}$ for ${ }^{1} \mathrm{H} \& 125 \mathrm{MHz}$ for ${ }^{13} \mathrm{C}$ ). The samples have been dissolved in (DMSO- $d_{6}$ ) using TMS as an internal reference, with the chemical shifts described in ppm, and coupling constants $(\mathrm{J})$ in Hz. (The analysis was done in Chemistry Department, College of Science, King Saud University, Riyadh, KSA). Negative electrospray ionization (ESI)-MS was accomplished using Thermo Finnigan LCQ Advantage MAX (ion trap) apparatus (Finnigan, Bremen, Germany). Samples were prepared in $10 \mu \mathrm{l}$ of $50 \%$ methanol. (The analysis was done in the central service LabNRC, Dokki, Giza, Egypt). UV Spectrophotometer Shimadzu UV 240 (P/N 240-58000) was used for recording different UV spectra while Jasco FT/IR6100 Spectrometer was used for recording IR spectra (The analysis was done in the central service LabNRC, Dokki, Giza, Egypt). All solvents used for the processes of extraction and separation were purchased from El Goumhoria Trade Pharmaceuticals and Chemicals, Cairo, Egypt.

\subsection{Plant material}

Collection of plant material was in September (2010) from the Zoo, Giza and the Agricultural Museum, Dokki, Giza. The identity of the plant was authenticated by Prof. Dr. Wafaa M. Amer, Botany Department, Faculty of Science, Cairo University. Voucher specimens (K1-3) are kept in the Department of Pharmacognosy, Faculty of Pharmacy, Al-Azhar University. The plant material was air- dried and powdered $(1.5 \mathrm{~kg})$ then kept in firmly closed container till extraction process.

\subsection{Preliminary phytochemical screening}

The air-dried powder of $K$. elegans twigs was screened for the presence of volatiles, carbohydrates and/or glycosides, alkaloids, saponins, tannins, anthraquinones, sterols and/or triterpenes, coumarins and flavonoids using standard methods of identification $^{16,17}$. Phenolic compounds were screened by 2D-PC using BAW for the first run and AA for the second run [BAW: $n$-butanol-acetic acidwater (4:1:5, top layer); AA: $15 \%$ aqueous acetic acid] and ferric chloride spray reagent for the detection of polyphenol spots ${ }^{18}$.

\subsection{Extraction and fractionation}

The powdered material $(1.5 \mathrm{~kg})$ was extracted using $70 \%$ methanol under reflux. The aqueous methanol extract was evaporated under vacuum at 50 ${ }^{\circ} \mathrm{C}$ to give total dry extract of $250 \mathrm{~g}$. Then the dry extract was defatted with petroleum ether and fractionated successively using ethyl acetate, $n$ butanol and methanol to give 4, 40, 130 and $45 \mathrm{~g}$ of each solvent respectively.

\subsection{Quantitative determination of phenolic content}

Quantitative estimation of total phenolic content of $K$. elegans twigs butanol extract was determined spectrophotometrically by the Folin Ciocalteus reagent method ${ }^{19}$. Gallic acid was administered as the standard for calibration curve preparation. Three replications were performed to estimate the total phenolic content measured as mg GAE (Gallic Acid Equivalents) per $1 \mathrm{~g}$ sample.

\subsection{Isolation of phytoconstituents}

The butanol fraction (130 g) was added to the column of polyamide S6 (Fluka, St. Louis, MO, USA) using a step gradient elution starting with water, then water/methanol mixture up to pure methanol to give six collective fractions (I-VI). Fraction I (eluted with $100 \%$ water, $10 \%$ methanol: water) was purified using silica gel column chromatography and gradient elution system of methylene chloride: methanol $(100: 0 \rightarrow 60: 40)$. The eluted fractions were monitored by TLC using methylene chloride: methanol in ratios of $9: 1,8.5: 1.5,8: 2$ and $7: 3$ as solvent systems according to elution polarity. The fractions were collected into three subfractions that were applied on sephadex LH-20 columns chromatography with ethanol as an eluting agent. Compound 1 was isolated from the first subfraction while compound 2 was isolated from the third subfraction. Each of fraction II (eluted with 20\% methanol: water and gives compounds 5 and 6), fraction III (eluted with 30\% methanol: water and gives compounds 3 and 4) and fraction IV (eluted with $40 \%$ methanol: water and gives compound 7 ) was added to successive column chromatography of both cellulose and sephadex LH-20 using water/methanol with decreasing polarity, BIW (butanol: isopropyl alcohol: water) and pure ethanol as eluting systems. Fraction V (eluted with $50-60 \%$ 
methanol: water) gave compound 8 by using silica gel column chromatography and methylene chloride: ethyl acetate step gradient as an eluting system. Then the collected subfraction was chromatographed on sephadex LH-20 with pure ethanol as an eluting solvent system. Fraction VI (eluted with $70-80 \%$ methanol: water) was subjected to silica gel column chromatography with methylene chloride, methylene chloride: ethyl acetate and ethyl acetate: methanol eluting system (in order of increasing polarity). Compound 9 was isolated from further purification on a silica gel column using ethyl acetate as eluent. Spectroscopic analysis, comparison with authentic samples (using CoPC) and published data were used to elucidate the structures of the isolated compounds.

\subsection{Brine shrimp lethality assay}

Ethyl acetate, butanol and methanol fractions of $K$. elegans twigs were preliminary evaluated for their cytotoxicity using BSLA which described by Meyer et al. $(1982)^{20}$. In brief, about $1 \mathrm{~g}$ of brine shrimp (Artemia salina) eggs was aerated for 48 hours in a separating funnel $(1 \mathrm{~L})$ containing sterile artificial seawater (prepared using 3.8\% NaCl solution, $\mathrm{pH}$ about 8.2 using $1 \mathrm{~N} \mathrm{NaOH}$ ). Newly hatched freeswimming nauplii (free from eggshells) were harvested from the bottom and used for the bioassay. Ten matured nauplii were applied to each watch glass that contains $10 \mathrm{ml}$ of artificial seawater, chosen fraction concentration and $1 \%$ yeast extract (for feeding). Count the number of survived nauplii and calculate the percent (\%) of mortality after 24 hours. The used concentrations of each fraction were 300 , 200, 100, 50, 10 and $5 \mathrm{ppm}(\mu \mathrm{g} / \mathrm{ml})$. Each concentration and a control test were prepared in triplicate.

\subsection{In-vitro cytotoxicity assay}

Cytotoxicity was tested in human breast, colon and lung carcinoma cell lines (MCF-7, HCT-116 and A-549 respectively). The tumor cell lines were seeded into 96-well plate in $100 \mu \mathrm{l}$ of growth medium at a cell concentration of $1 \times 10^{4}$ cells per well. The monolayers were then washed with sterile phosphate buffered saline ( $0.01 \mathrm{M}, \mathrm{pH} 7.2)$ after $24 \mathrm{~h}$ of seeding, and the cells were simultaneously treated with $100 \mu \mathrm{l}$ from different dilutions of the test sample in fresh maintenance medium and incubated at $37^{\circ} \mathrm{C}$. Using a multichannel pipette, serial two-fold dilutions of the tested compounds $(100,50,25,12.5,6.25$ and 3.125 $\mu \mathrm{g} / \mathrm{ml})$ were applied to confluent cell monolayers dispensed into 96-well, flat-bottomed microtiter plates. Then the plates were incubated at $37^{\circ} \mathrm{C}$ in a humidified incubator with $5 \% \mathrm{CO}_{2}$ for a period of 24 h. Untreated cells were used as controls. Three independent experiments were carried out, each containing six replicates for each concentration of the samples studied. The cytotoxic effects of the samples examined (butanol extract and the isolated compounds) were then measured using crystal violet staining viability assay ${ }^{21,22}$.

\section{RESULTS}

\subsection{Phytochemical analysis:}

The preliminary phytochemical screening of $K$. elegans twigs crude powder showed the presence of saponins, carbohydrates and/or glycosides, sterols and/or triterpenes, flavonoids, tannins and traces of alkaloids while volatiles, anthraquinone and coumarins were absent.

\subsection{Total phenolic content}

The total phenolic content of butanol fraction of $K$. elegans twigs was evaluated as GAE concerning a standard curve. The measured phenolic content was $260 \mathrm{mg}$ of GAE per $1 \mathrm{~g}$ dry sample (Figure 1).

\subsection{Characterization of isolated compounds}

In this study, 9 compounds mainly polyphenolics were identified in the butanol fraction of $K$. elegans twigs. All compounds were characterized using chemical and physicochemical investigations. Also, identification was carried out by comparison with published data and/or authentic reference compounds. The following data demonstrated the spectroscopic and chromatographic behaviour of the isolated compounds, while their structures were shown in Supplementary Table (1):

\subsubsection{Compound 1:}

Off-white amorphous powder (30 mg), m.p 251$253^{\circ} \mathrm{C}, \mathrm{R}_{\mathrm{f}}$ values: 0.56 (BAW) and $0.73(\mathrm{AA})$ on $\mathrm{PC}$, shine violet fluorescence under short UV light, turned to deep blue color with $\mathrm{FeCl}_{3}$. UV spectral data, $\lambda_{\max }$ (nm) $(\mathrm{MeOH}): 272$. Negative ESI-MS: $m / z 169$ [MH] $.{ }^{1} \mathrm{H}-\mathrm{NMR}$ spectral data $\left(500 \mathrm{MHz}, \mathrm{DMSO}-d_{6}\right): \delta$ ppm $6.91(2 \mathrm{H}, \mathrm{s}, \mathrm{H}-2 / 6) .{ }^{13} \mathrm{C}-\mathrm{NMR}$ spectral data $(125$ MHz, DMSO- $\left.d_{6}\right): \delta$ ppm 108.81(C-2/6), 120.54 (C1), 138.07 (C-4), 145.49(C-3/5) and 167.57 (COO). The compound was characterized as $3,4,5-$ trihydroxy-benzoic acid (gallic acid) ${ }^{23}$.

\subsubsection{Compound 2:}

White amorphous powder (70 mg), m.p 204-205 ${ }^{\circ} \mathrm{C}, \mathrm{R}_{\mathrm{f}}$ values: 0.61 (BAW) and 0.70 (AA) on $\mathrm{PC}$, shine violet fluorescence under short UV light, turned to deep blue color with $\mathrm{FeCl}_{3}$. UV spectral data, $\lambda_{\max }$ (nm) $(\mathrm{MeOH}): 273$. Negative ESI-MS: $m / z 183$ [M$\mathrm{H}]-.{ }^{1} \mathrm{H}-\mathrm{NMR}$ spectral data $\left(500 \mathrm{MHz}, \mathrm{DMSO}-d_{6}\right): \delta$ ppm $3.76\left(3 \mathrm{H}, \mathrm{s}, \mathrm{OCH}_{3}\right), 6.96(2 \mathrm{H}$, brs, $\mathrm{H}-2 / 6)$ and $9.19(\mathrm{OH}) .{ }^{13} \mathrm{C}-\mathrm{NMR}$ spectral data $(125 \mathrm{MHz}$, DMSO- $\left.d_{6}\right): \delta$ ppm $51.68\left(\mathrm{OCH}_{3}\right), 108.57(\mathrm{C}-2 / 6)$, 119.36 (C-1), 138.48(C-4), 145.65(C-3/5) and $166.41(\mathrm{COO})$. The compound was characterized as methyl gallate ${ }^{24}$ 


\subsubsection{Compound 3:}

White amorphous powder $(28 \mathrm{mg}), \mathrm{R}_{\mathrm{f}}$ values: 0.16 (BAW) and 0.66 (AA) on $\mathrm{PC}$, shine violet fluorescence under short UV light, turned to deep blue color with $\mathrm{FeCl}_{3}$. UV spectral data, $\lambda_{\max }(\mathrm{nm})$ $(\mathrm{MeOH}): 220,276$. The acid hydrolysis of this compound gave 4-methoxy gallic acid in organic phase and glucose in aqueous phase which were identified by Co-TLC with authentic samples. Negative ESI-MS: m/z 345 [M-H]- ${ }^{1} \mathrm{H}-\mathrm{NMR}$ spectral data $\left(500 \mathrm{MHz}, \mathrm{DMSO}-d_{6}\right): \delta \mathrm{ppm} 3.70,3.73$ each $\left(3 \mathrm{H}, \mathrm{s}, \mathrm{OCH}_{3}\right), 6.89,6.92$ each $(2 \mathrm{H}, \mathrm{s}, \mathrm{H}-2 / 6)$; Glucose moieties: $3.90,3.50 \mathrm{(3H}, \mathrm{m}, \mathrm{H}-2,3,4$ in $\alpha$, $\beta$-isomers), 4.15, 4.50 ( $3 \mathrm{H}$ in total, $\mathrm{m}, \mathrm{H}-5, \mathrm{H}-6 \mathrm{a} / 6 \mathrm{~b}$ in $\alpha, \beta$-isomers $), 4.80(1 / 3 \mathrm{H}, \mathrm{d}, \mathrm{J}=7.8 \mathrm{~Hz}, \mathrm{H}-1 \beta), 5.25$ $(2 / 3 \mathrm{H}, \mathrm{d}, \mathrm{J}=3.4, \mathrm{H}-1 \alpha) \cdot{ }^{13} \mathrm{C}-\mathrm{NMR}$ spectral data $(125$ $\left.\mathrm{MHz}, \mathrm{DMSO}-d_{6}\right): \delta$ ppm $60.34,60.51\left(4-\mathrm{OCH}_{3}\right.$ in $\alpha, \beta$-isomers), 108.82 represents four carbons $\left(\mathrm{C}-2^{\prime} / 6^{\prime}\right.$ in $\alpha, \beta$-isomers), $119.33,118.67$ (C-1' in $\alpha, \beta$-isomers), $138.95,138.67$ (C-4' in $\alpha, \beta$-isomers), $145.79,145.58$ (C-3'/5' in $\alpha, \beta$-isomers), 165.177 represents two carbons ( $\mathrm{C}-7$ in $\alpha, \beta$-isomers); Glucose moieties:

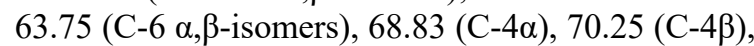
$71.12(\mathrm{C}-5 \alpha), 72.44(\mathrm{C}-2 \alpha), 74.10(\mathrm{C}-3 \alpha), 74.81$ (C-

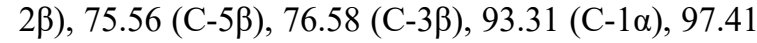
$(\mathrm{C}-1 \beta)$. The compound was characterized as 6-O(Galloyl 4- methyl ether)-( $\alpha / \beta)$-D-glucopyranose ${ }^{25}$.

\subsubsection{Compound 4:}

Buff amorphous powder $(32 \mathrm{mg}), \mathrm{R}_{\mathrm{f}}$ values: 0.48 (BAW) and 0.58 (AA) on $\mathrm{PC}$, shine violet fluorescence under short UV light, turned to deep blue color with $\mathrm{FeCl}_{3}$. UV spectral data, $\lambda_{\max }(\mathrm{nm})$ $(\mathrm{MeOH}): 273$. The acid hydrolysis of this compound gave gallic acid and quinic acid in organic phase using CoPC ( $\mathrm{R}_{\mathrm{f}}$ values; 0.71 for gallic acid and 0.79 for quinic acid in solvent system S6). Negative ESI-MS: $\mathrm{m} / \mathrm{z} 551[\mathrm{M}-\mathrm{H}]^{-} .{ }^{1} \mathrm{H}-\mathrm{NMR}$ and ${ }^{13} \mathrm{C}-\mathrm{NMR}$ spectral data of compound $4(500 \mathrm{MHz}, 125 \mathrm{MHz}$ respectively, DMSO- $d_{6}$ ) were represented in [Supplementary Table (2)]. The compound was characterized as 3, 5-di-Ogalloylquinic acid butyl ester.

\subsubsection{Compound 5:}

Dark buff amorphous powder (36 mg), $\mathrm{R}_{\mathrm{f}}$ values: 0.32 (BAW) and 0.61 (AA) on PC, the same chromatographic properties on $\mathrm{PC}$ as the previous compound. UV spectral data, $\lambda_{\max }(\mathrm{nm})(\mathrm{MeOH}): 272$. The acid hydrolysis of this compound gave gallic acid and quinic acid in organic phase using $\mathrm{CoPC}\left(\mathrm{R}_{\mathrm{f}}\right.$ values; 0.72 for gallic acid and 0.81 for quinic acid in solvent system S6). Negative ESI-MS: $m / z 703$ [M$\mathrm{H}]$. ${ }^{1} \mathrm{H}-\mathrm{NMR}$ and ${ }^{13} \mathrm{C}-\mathrm{NMR}$ spectral data of compound $4(500 \mathrm{MHz}, 125 \mathrm{MHz}$ respectively,
DMSO- $d_{6}$ ) were represented in [Supplementary Table (2)]. The compound was characterized as 3,4,5-tri- $O$ galloylquinic acid butyl ester ${ }^{26}$.

\subsubsection{Compound 6:}

Dark buff amorphous powder $(41 \mathrm{mg}), \mathrm{R}_{\mathrm{f}}$ values: 0.25 (BAW) and 0.69 (AA) on PC, the same chromatographic properties on $\mathrm{PC}$ as the previous compounds. UV spectral data, $\lambda_{\max }(\mathrm{nm})(\mathrm{MeOH})$ : 274. The acid hydrolysis of this compound gave gallic acid and quinic acid in organic phase using $\mathrm{CoPC}\left(\mathrm{R}_{\mathrm{f}}\right.$ values; 0.72 for gallic acid and 0.78 for quinic acid in solvent system S6). Negative ESI-MS: $m / z 855$ [M$\mathrm{H}]^{-}$. ${ }^{1} \mathrm{H}-\mathrm{NMR}$ and ${ }^{13} \mathrm{C}-\mathrm{NMR}$ spectral data of compound $4(500 \mathrm{MHz}, 125 \mathrm{MHz}$ respectively, DMSO- $d_{6}$ ) were represented in [Supplementary Table (2)]. The compound was characterized as $1,3,4,5-$ tetra- $O$-galloylquinic acid butyl ester.

\subsubsection{Compound 7:}

White amorphous powder (37 mg), $\mathrm{R}_{\mathrm{f}}$ values: 0.49 (BAW) and 0.59 (AA) on PC, the same chromatographic properties on $\mathrm{PC}$ as the previous compounds. UV spectral data, $\lambda_{\max }(\mathrm{nm})(\mathrm{MeOH})$ : 272. The acid hydrolysis of this compound gave gallic acid and quinic acid in organic phase using CoPC $\left(\mathrm{R}_{\mathrm{f}}\right.$ values; 0.69 for gallic acid and 0.79 for quinic acid in solvent system S6). Negative ESI-MS: $m / z 399$ [M$\mathrm{H}]-{ }^{1} \mathrm{H}-\mathrm{NMR}$ spectral data $\left(500 \mathrm{MHz}, \mathrm{DMSO}-d_{6}\right): \delta$ ppm for quinic acid moiety: $\delta 2.11(2 \mathrm{H}, \mathrm{m}, \mathrm{H}-2), 2.50$ $(2 \mathrm{H}, \mathrm{m}, \mathrm{H}-6), 5.37$ (1H, brd, H-4), $5.50(2 \mathrm{H}, \mathrm{m}, \mathrm{H}-$ $3 / 5)$, butyl group: $\delta 0.88(3 \mathrm{H}, \mathrm{t}), 1.27(2 \mathrm{H}, \mathrm{m}), 1.29$ $(2 \mathrm{H}, \mathrm{m}), 3.39(2 \mathrm{H}, \mathrm{t})$, galloyl moieties: two galloyl moieties $\delta 6.87,6.90(2 \mathrm{H}, \mathrm{s}, \mathrm{H}-2 / 6) .{ }^{13} \mathrm{C}-\mathrm{NMR}$ spectral data (125 MHz, DMSO-d6): $\delta$ ppm showed duplication of signals for each of quinic acid moiety, butyl moiety and galloyl group at 13.58, 13.90, (C11), 18.51, 18.69 (C-10), 35.50, 35.60 (C-2), 39.50 (C-9), 39.80 (C-6), 60.30, 60.43 (C-8), 68.02 (C-3), 69.01 (C-5), 72.30, 72.40 (C-1), 74.50 (C-4), 172.20 (C-7) [COOR of quinic acid], 108.82, (represents four carbons) [galloyl 2,6], 118.67, 119.32 [galloyl 1], 138.67, 138.95 [galloyl 4], 145.47, 145.59 [galloyl 3,5 ], 164.63, 164.82 [galloyl COO]. Compound 7 was characterized to be two isomers of 3-O-galloyl quinic acid butyl ester and 4-O-galloyl quinic acid butyl ester $^{27}$.

\subsubsection{Compound 8:}

White needle crystals (50 mg), m.p $183-185^{\circ} \mathrm{C}$, $\mathrm{R}_{\mathrm{f}}$ value: 0.84 (BAW). UV spectral data, $\lambda_{\max }(\mathrm{nm})$ $(\mathrm{MeOH}): 244$ and 288. IR spectral data, $\mathrm{cm}^{-1}$ : distinctive large, intense band at $2917\left(\mathrm{CH}_{2}\right.$ and $\mathrm{CH}$ alkyl groups), 1769 ( $\gamma$-lactone), 1644 (aromatic), 1207 (C-O groups), 805 (methylenedioxy). Negative ESI-MS: $m / z 381[\mathrm{M}-\mathrm{H}]^{-}$. ${ }^{1} \mathrm{H}-\mathrm{NMR}$ and ${ }^{13} \mathrm{C}-\mathrm{NMR}$ 
spectral data of compound $9(500 \mathrm{MHz}, 125 \mathrm{MHz}$ respectively, DMSO- $d_{6}$ ) were represented in Table (3). The compound was characterized as austrobailignan $1^{10}$.

\subsubsection{Compound 9:}

White powder $(20 \mathrm{mg})$, m.p $134-135{ }^{\circ} \mathrm{C}, \mathrm{R}_{\mathrm{f}}$ value: 0.91 (BAW). It gave positive Liebermann Burchard and Salkowski tests and negative Molisch's test. IR spectral data, $\mathrm{cm}^{-1}$ : broad absorption band at 3420 (OH group), 1108 and 1054 for C-O stretching vibrations. Negative ESI-MS: $m / z 414[\mathrm{M}-\mathrm{H}]^{-} .{ }^{1} \mathrm{H}-$ NMR and ${ }^{13} \mathrm{C}$-NMR spectral data of compound 10 $\left(500 \mathrm{MHz}, 125 \mathrm{MHz}\right.$ respectively, DMSO- $d_{6}$ ) were represented in Supplementary Table (4). The compound was characterized as $\beta$-sitosterol ${ }^{28}$.

\subsection{Brine shrimp lethality assay}

BSLA was conducted to evaluate the active cytotoxic fractions. Ethyl acetate, butanol and methanol fractions of $K$. elegans twigs showed good brine shrimp larvicidal activity as $\mathrm{LC}_{50}$ of them were $75 \mathrm{ppm}(\mu \mathrm{g} / \mathrm{ml}), 83 \mathrm{ppm}$, and $132 \mathrm{ppm}$ respectively. The activity of all fractions was found to be concentration dependent (Figure (2)).

\subsection{In-vitro cytotoxicity assay}

In-vitro cytotoxicity of butanol fraction, compound 2 (methyl gallate) and compound 8 (austrobailignan 1) was evaluated against HCT-116, MCF-7 and A-549 carcinoma cell lines using viability assay at six different sample concentrations $(100,50$, $25,12.5,6.25$ and $3.125 \mu \mathrm{g} / \mathrm{ml}$ ). The results revealed that the butanol fraction of $K$. elegans twigs does not have cytotoxic activity against both A-549 and HCT116 while it has weak cytotoxic activity against MCF7. Methyl gallate pure isolated compound showed weak cytotoxic activity against A-549 and good cytotoxicity against both HCT-116 and MCF-7 with $\mathrm{IC}_{50}=95.5$ and $48.6 \mu \mathrm{g}$ respectively while, austrobailignan 1 the pure other isolated compound does not have cytotoxic activity against A-549 but it has shown significant cytotoxicity against both HCT116 and MCF-7 with $\mathrm{IC}_{50}=77.4$ and $40.4 \mu \mathrm{g}$ respectively Supplementary (Supplementary Table (5), Figures (3-5)).

\section{DISCUSSION}

Cancer is an ancient disease that continues to be a threat to humankind. Subsequently, discovering compelling and safe treatments is the require of the hour. Investigation of plants' secondary metabolites represents a promising trend for cancer research. Presently, BSLA is an efficient, inexpensive and simple technique for preliminary cytotoxicity screening of plant extracts ${ }^{29}$. In this study, the preliminary cytotoxicity of $K$. elegans twigs ethyl acetate, butanol and methanol fractions was estimated using BSLA as a bioassay guide. The three fractions exhibited good brine shrimp larvicidal activities that were concentration dependent. The $\mathrm{LC}_{50}$ of the three fractions were 75,83 and $132 \mathrm{ppm}$ respectively. According to Meyer et al. (1982), if the $\mathrm{LC}_{50}$ value of the crude plant extract is less than $1000 \mathrm{ppm}$ it is considered toxic (active) while be non-toxic if its $\mathrm{LC}_{50}$ value is greater than $1000 \mathrm{ppm}^{20}$. Since, both butanol and ethyl acetate fractions almost possessed the same $\mathrm{LC}_{50}$ value, the butanol fraction was used to isolate bioactive constituents due to its abundant quantity $(130 \mathrm{~g})$ and richness in phenolic substances. The quantitative estimated phenolic content of butanol fraction was $260 \mathrm{mg} \mathrm{GAE} / \mathrm{g}$.

The butanol fraction was chromatographed on a polyamide column followed by sequential separation on silica gel, cellulose and sephadex LH-20 columns to afford nine pure compounds (eight polyphenolics and one sitosterol). Structure elucidation of these compounds was conducted using UV, NMR and ESI mass spectrometry as well as comparison with authentic standards and published data. It is the first time for isolation of all these compounds from twigs of $K$. elegans. Among these was compound 2 (70 $\mathrm{mg}$ ), that exhibited typical chromatographic and UV spectral data of gallotannins with molecular ion peak at $m / z \quad 183[\mathrm{M}-\mathrm{H}]^{-}$in negative ESI-MS that corresponding to a molecular weight of 184 . This data is consistent with molecular formula $\mathrm{C}_{8} \mathrm{H}_{8} \mathrm{O}_{5}$ which agreed with the number of protons and carbons contained in the compound's corresponding ${ }^{1} \mathrm{H}$ and ${ }^{13} \mathrm{C}-\mathrm{NMR}$ spectra. From the previous details and comparing with authentic samples (using CoPC) and reported data ${ }^{24}$, compound 2 was interpreted as methyl gallate. Compound 8 (white needle crystals, $50 \mathrm{mg}$ ) revealed a molecular ion peak $[\mathrm{M}-\mathrm{H}]^{-}$at $\mathrm{m} / \mathrm{z}$ 381 in negative ESI-MS that suggested a molecular formula of $\mathrm{C}_{21} \mathrm{H}_{18} \mathrm{O}_{7}$ that agreed with the number of protons and carbons present in its corresponding spectra of ${ }^{1} \mathrm{H}$ and ${ }^{13} \mathrm{C}-\mathrm{NMR}$. Compound 8 IR spectrum revealed absorption bands correlated with a conjugated $\gamma$-lactone $\left(1769 \mathrm{~cm}^{-1}\right)$ and a methylenedioxy ether $\left(805 \mathrm{~cm}^{-1}\right)$. The presence of a lactone in the structure was confirmed by the carbonyl carbon resonance signal at $(\delta$ 174.87) and the resonance signal of methylene carbon connected to oxygen at $(\delta 71.50)$ in the ${ }^{13} \mathrm{C}-\mathrm{NMR}$ spectrum. While ${ }^{1} \mathrm{H}-\mathrm{NMR}$ spectrum showed the signals of four aromatic protons at $\delta 6.76,6.48,6.38$ and 6.06. The ${ }^{1} \mathrm{H}-\mathrm{NMR}$ spectrum also included one methyl proton signal at $\delta 3.74$, two methylendioxy signals at $\delta 5.905$ and $5.908(1 \mathrm{H}$ each, $J=1.5 \mathrm{~Hz})$ and a singlet at $\delta 5.95$ $(2 \mathrm{H}) \mathrm{ppm}$. These functional groups were validated by the presence of ${ }^{13} \mathrm{C}-\mathrm{NMR}$ signals at $\delta 56.31\left(\mathrm{CH}_{3}\right)$, $100.91\left(\mathrm{CH}_{2}\right)$ and $101.05\left(\mathrm{CH}_{2}\right)$. Therefore, the Aring of the compound must have 3', 4'methylenedioxy and $5{ }^{\prime}$-methoxy substituents. From the above data and comparing with reported data ${ }^{10}$, this compound was identified as Austrobailignan 1. 
In-vitro cytotoxicity assay of $K$. elegans butanol fraction, compound 2 (methyl gallate) and compound 8 (austrobailignan 1( against MCF-7, HCT-116 and A-549 carcinoma cell lines using viability assay demonstrated promising anticancer activity of both methyl gallate and austrobailignan 1 against MCF-7 cell lines. As methyl gallate and austrobailignan 1 reduced the cell proliferation of MCF-7 cell lines with an $\mathrm{IC}_{50}$ values of 48.6 and $40.4 \mu \mathrm{g} / \mathrm{ml}$ respectively. They also exhibited weak anticancer activity against HCT-116 cell lines with $\mathrm{IC}_{50}$ values of 95.5 and 77.4 for methyl gallate and austrobailignan 1 respectively, while they did not show any cytotoxic activity against A-549 cell lines. As the extract is accepted as active against cancer cell lines when $\mathrm{IC}_{50}$ value is $<100$ $\mu \mathrm{g} / \mathrm{ml}^{30}$.

\section{CONCLUSIONS}

The present study demonstrates the significant phenolic content of $K$. elegans twigs butanol fraction and the evaluation of antiproliferative activity of this fraction and its two major components methyl gallate and austrobailignan 1 against three different cancer cell lines. Both methyl gallate and austrobailignan 1 exhibited promising anticancer activity against MCF7 cancer cell lines. Future studies should be focused on cytotoxic mechanisms of these compounds and investigation of other pharmacological activities of $K$. elegans twigs depending on its high content of phenolic compounds.

Conflict of interest: All authors declared no conflict of interest.

Author contribution: All authors contributed significantly in writing, revising, and editing the manuscript.

Funding: This research received no external funding.

\section{REFERENCES}

1. Adloye D, Grant L. A review of cancers in Africa. Chronic Non-Communicable Dis. Low Middle-income Ctries. (eds A. de-Graft Aikins C. Agyemang), 2015, p. 14-29.

2. WHO. Fact sheet: Cancer. World Heal Organ 2018. https://www.who.int/newsroom/fact-sheets/detail/cancer.

3. Fernando W, Rupasinghe HP. Anticancer properties of phytochemicals present in medicinal plants of North America. Using old Solut. to new Probl. drug Discov. 21st century. Second edi, 2015.

4. Cai Y, Luo Q, Sun M, Corke H. Antioxidant activity and phenolic compounds of 112 traditional Chinese medicinal plants associated with anticancer. Life Sci 2004;74:2157-84.

5. Meyer F. A revision of the genus Koelreuteria (Sapindaceae). J Arnold Arbor1976;57:129-66.

6. Carlson H, Olynyk P, Duncan H, Smolin A. The chemical, physical, and antibiotic properties of methyl gallate isolated from Koelrenteria paniculata. Antibiot Chemother 1951;1:431-42.

7. Ghahari S, Alinezhad H, Nematzadeh GA, Ghahari S. Phytochemical screening and antimicrobial activities of the constituents isolated from Koelreuteria paniculata leaves. Nat Prod Res 2015;29:1865-9.

8. Hartzell A. Additional tests of plant products for insecticidal properties and summary of results to date. Contrib Boyce Thompson Inst Plant Res 1947;15.

9. Hatano $\mathrm{T}$, Yasuhara $\mathrm{T}$, Yoshihara R, Ikegami Y, Matsuda M, Yazaki K, et al. Inhibitory effects of galloylated flavonoids on xanthine oxidase. Planta Med 1991;57:83-4.

10. Song Y-N, Zhang H-L, Chang C, Bollag DM. Cytotoxic cyclolignans from Koelreuteria henryi. J Nat Prod 1994;57:1670-4.

11. Abou-Shoer M, Ma G-E, Li X-H, Koonchanok NM, Geahlen RL, Chang C-J. Flavonoids from Koelreuteria henryi and other sources as protein-tyrosine kinase inhibitors. J Nat Prod 1993;56:967-9.

12. Chiang Y-Y, Wang S-L, Yang C-L, Yang HY, Yang H-C, Sudhakar JN, et al. Extracts of Koelreuteria henryi Dummer induce apoptosis and autophagy by inhibiting dihydrodiol dehydrogenase, thus enhancing anticancer effects. Int $\mathrm{J}$ Mol Med 2013;32:577-84.

13. Wu C-C, Huang K-F, Yang T-Y, Li Y-L, Wen C-L, Hsu S-L, et al. The Topoisomerase 1 inhibitor austrobailignan-1 isolated from Koelreuteria henryi induces a G2/M-phase arrest and cell death independently of p53 in non-small cell lung cancer cells. PLoS One 2015;10:e132052. 
14. Liang S, Ma B. Advances in researches on chemical compositions of Koelreuteria paniculata. Journal-Northwest for Univ 2004;19:119-22.

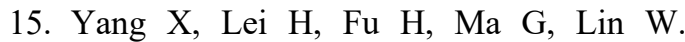
Chemical constituents from the seeds of Koelreuteria paniculata Laxm. Acta Pharm Sin 2000;35:279-83.

16. Harborne AJ. Phytochemical methods a guide to modern techniques of plant analysis. springer science $\&$ business media; 1998.

17. WC E. Trease and Evans pharmacognosy. Nottingham Univ Nottingham 2002:21.

18. Mabry T, Markham KR, Thomas MB. The systematic identification of flavonoids. Springer Science \& Business Media; 2012.

19. Singleton VL, Orthofer R, LamuelaRaventós RM. Analysis of total phenols and other oxidation substrates and antioxidants by means of Folin-ciocalteu reagent. Methods Enzymol 1999;299:152-78.

20. Meyer BN, Ferrigni NR, Putnam JE, Jacobsen LB, Nichols DE j, McLaughlin JL. Brine shrimp: a convenient general bioassay for active plant constituents. Planta Med $1982 ; 45: 31-4$.

21. Gangadevi V, Muthumary J. Preliminary studies on cytotoxic effect of fungal taxol on cancer cell lines. African J Biotechnol 2007;6.

22. Mosmann T. Rapid colorimetric assay for cellular growth and survival: application to proliferation and cytotoxicity assays. J Immunol Methods 1983;65:55-63.

23. Meshram G, Patil B, Yadav S, Shined D. Isolation and characterization of gallic acid from Terminalia bellerica and its effect on carbohydrate regulatory system in vitro. Int J Res Ayurveda Pharm 2011;2:559-62.

24. Ekaprasada MT, Nurdin H, Ibrahim S, Dachriyanus D. Antioxidant activity of methyl gallate isolated from the leaves of Toona sureni. Indones J Chem 2009;9:45760.

25. Hsu F-L, Lee Y-Y, Cheng J-T.
Antihypertensive activity of 6-O-galloyl-Dglucose, a phenolic glycoside from Sapium sebiferum. J Nat Prod 1994;57:308-12.

26. Moore JP, Westall KL, Ravenscroft N, Farrant JM, Lindsey GG, Brandt WF. The predominant polyphenol in the leaves of the resurrection plant Myrothamnus flabellifolius, 3, 4, 5 tri-O-galloylquinic acid, protects membranes against desiccation and free radical-induced oxidation. Biochem J 2005;385:301-8.

27. Nishimura H, Nonaka G-I, Nishioka I. Seven quinic acid gallates from Quercus stenophylla. Phytochemistry 1984; 23:26213.

28. Habib MR, Nikkon F, Rahman M, Haque ME, Karim MR. Isolation of stigmasterol and beta-sitosterol from methanolic extract of root bark of Calotropis gigantea (Linn). Pak J Biol Sci 2007;10:4174-6.

29. Mwiti CK, Afolayan JA. Antifungal activity and brine shrimp toxicity assessment of Bulbine abyssinica used in the folk medicine in the Eastern Cape Province, South Africa 2016.

30. Karakas FP, Yidirim AB, Bayram R, Yavuz MZ, Gepdiremen A, Turker AU. Antiproliferative activity of some medicinal plants on human breast and hepatocellular carcinoma cell lines and their phenolic contents. Trop J Pharm Res 2015;14:178795 . 